УДК 339.1; 338.1

\title{
РОЗРОБКА МЕХАНІЗМУ ОЦІНЮВАННЯ ПРОЦЕСУ МОДЕРНІЗАЦІЇ ГАЗОТРАНСПОРТНОЇ СИСТЕМИ В УМОВАХ СТАЛОГО РОЗВИТКУ
}

\section{DEVELOPMENT OF MECHANISM FOR EVALUATION OF GTS MODERNIZATION PROCESS IN CONDITIONS OF SUSTAINABLE DEVELOPMENT}

\author{
Перевозова Ірина Володимирівна \\ доктор економічних наук, професор, \\ Івано-Франківський національний технічний університет нафрти і газу \\ ORCID: https://orcid.org/0000-0002-3878-802X \\ Лісова Оксана Василівна \\ аспірантка кафедри підприємництва та маркетингу \\ Івано-Франківський національний технічний університет нафрти і газу \\ ORCID: https://orcid.org/0000-0003-3941-7295 \\ Perevozova Iryna, Lisova Oksana \\ Ivano-Frankivsk National Technical University of Oil and Gas
}

\begin{abstract}
В статті проаналізовано динаміку виробництва та імпорту природного газу. Встановлено, що при розробці механізму оцінки модернізації газотранспортної системи (далі ГТС) необхідно враховувати досвід впровадження проектів оцінки, які використовують експериментальний та квазіекспериментальний фрормати. Запропоновано використовувати розширений механізм оцінки модернізації ГТС на основі представлення підсумкової оцінки та аналізу. Визначено переваги модернізації застарілої ГТС. Зокрема, операційна ефективність: модернізована система забезпечить кращу продуктивність, швидший час транспортування та кращий досвід для внутрішніх та зовнішніх клієнтів; зниження витрат: виведення з експлуатації неефективного обладнання зменшує витрати на забезпечення діяльності; оптимізація процесів, адаптація до умов бізнесу або швидке використання інноваційних можливостей, щоб перемогти своїх конкурентів на глобальному ринку.

Ключові слова: газотранспортна система України, газ, паливно-енергетичний комплекс, потужність, енергетична безпека, транспортування.
\end{abstract}

В статье проанализирована динамика производства и импорта природного газа. Установлено, что при разработке механизма процесса модернизации газотранспортной системы (далее ГТС), необходимо учитывать опыт внедрения проектов оценки, которые используют экспериментальный и квазиэкспериментального фрорматы. Предложено использовать расширенный механизм оценки модернизации ГТС на основе представления итоговой оценки и анализа. Определены преимущества модернизации устаревшей ГТС. В частности, операционная эффективность: модернизированная система обеспечит лучшую производительность, быстрый транспортировке и лучший опыт для внутренних и внешних клиентов; снижение расходов: выведение из эксплуатации неэффективного оборудования уменьшает расходы на обеспечение деятельности; оптимизация процессов, адаптация к условиям бизнеса или быстрое использование инновационных возможностей, чтобы победить своих конкурентов на глобальном рынке.

Ключевые слова: газотранспортная система Украины, газ, топливно-энергетический комплекс, мощность, энергетическая безопасность, транспортировки.

Modern conditions dictate the volume of transportation and the service life of the equipment. The domestic gas transmission system is loaded by less than a third of its transit capacity and needs to be optimized, where the Ukrainian gas transportation system is designed for transit of 146 billion cubic meters per year. In 2019, according to the transit contract, it amounted to 60 billion cubic meters. Modernization of the gas transmission system should begin with an understanding of current and new needs of users, and then an understanding of existing infrastructure, technologies and resources. Asking the right questions before upgrading an outdated system, it is crucial to use the tools and mechanism to evaluate the upgrade process in a sustainable environment. The purpose of the article was 
to substantiate the mechanism for evaluating the process of modernization of the gas transmission system in terms of sustainable development. The dynamics of natural gas production and import is analyzed. When developing a mechanism for assessing the modernization of the gas transmission system, two points must be taken into account: first, the recognition that significant improvement is both necessary and feasible (albeit costly) in evaluating the gas transmission system modernization program; and second, taking into account the experience of implementing formal evaluation projects, especially those that use experimental and quasi-experimental formats. From this position, an extended mechanism for assessing the modernization of the gas transmission system is proposed on the basis of presenting the final assessment and analysis of the current state of knowledge. The advantages of modernization of the outdated gas transmission system are determined. In particular, operational efficiency: the upgraded system will provide better performance, faster transportation time and better experience for internal and external customers; cost reduction: decommissioning of inefficient equipment reduces operating costs; process optimization, adaptation to business conditions or rapid use of innovative opportunities to beat its competitors in the global market.

Keywords: gas transmission system of Ukraine, gas, fuel and energy complex, capacity, energy security, transportation.

Актуальність дослідження. Вітчизняна ГТС завантажена менш ніж на третину своєї транзитної потужності й потребує оптимізації. щоб ефективніше управляти ГТС та забезпечити клієнтам та українським споживачам економічно обґрунтований тарифр навіть за умови зупинки транзиту Росією, Оператор ГТС України намагається проводити масштабну її модернізацію.

Сучасні умови диктують обсяги транспортування та терміни експлуатації обладнання. Українська газотранспортна система розрахована на транзит у 146 млрд кубометрів за рік. У 2019 році, згідно з чинним транзитним контрактом, він склав до 60 млрд кубометрів. 3 урахуванням таких реалій повинні бути визначені об'єкти, задіяні в транспортуванні газу, видобутого в Україні, і забезпеченні імпорту з ЄС. Таким чином, існує необхідність суттєвої оптимізації роботи ГТС і в подальшому, вкладання коштів лише в ті об'єкти, які будуть реально задіяні.

Аналіз останніх досліджень і публікацій. Проблемам теорії та практики ефрективного фоннцціонування і пошуку шляхів розвитку та модернізації газотранспортної системи України присвячено праці таких учених, як Бобрівець С., Гелетуха Г., Крижанівський $€$., Дзьоба О., Джус А., Міронов Ю., Кулицький С., Кучмистенко О., Павлов К., Полянська А. [1-7].

Науковці приділяють велику увагу у своїх роботах темі ефективного використання ГТС України, здійснення оптимальної диверсиорікації джерел постачання паливно-енергетичних ресурсів та збереження статусу транзитної держави. Проте, недостатньо дослідженими залишаються питання розробки механізму оцінки модернізації газотранспортної системи в умовах сталого розвитку.

Мета дослідження - обґрунтувати механізм оцінювання процесу модернізації ГТС в умовах сталого розвитку.
Виклад основного матеріалу. Модернізація газотранспортної системи повинна починатися з розуміння поточних і нових потреб користувачів, а потім розуміння наявної інфрраструктури, технологій і ресурсів. Задаючи правильні питання перед модернізацією застарілої системи, вирішальне значення має використання інструментів та механізму оцінки процесу модернізації в умовах сталого розвитку. На рис. 1 проаналізовано динаміку виробництва та імпорту природного газу, тисяч тонн нафртового еквіваленту.

Згідно рисунку 1, можемо зробити висновок, що виробництво природного газу в Україні зросло на 5 \% у 2019 році порівняно 3 2012 роком. При цьому імпорт природного газу скоротився на 65 \% за досліджуваний період.

В сучасних реаліях існують великі надлишкові транзитні потужності газотранспортної системи. Чимало об'єктів газотранспортної системи вже не задіяні, які фрактично складають половину від встановленої потужності ГТС. Усі ці об'єкти підлягають оптимізації та модернізації.

При розробці механізму процесу оцінки модернізації газотранспортної системи необхідно враховувати два моменти: по-перше, визнання того, що значне поліпшення $є$ як необхідним, так і здійсненним (хоча і затратним) при оцінці програми модернізації газотранспортної системи; і по-друге, врахування досвіду впровадження офріційних проектів оцінки, особливо тих, що використовують експериментальний та квазіекспериментальний фрормати. 3 цієї позиції пропонується розширений механізм оцінки модернізації газотранспортної системи на основі представлення підсумкової оцінки та аналізу сучасного стану знань.

Визначено декілька напрямків розширеного механізму оцінки процесу модернізації. У кожному випадку оцінка розглядається як засіб одночасного отримання інформації, що має 


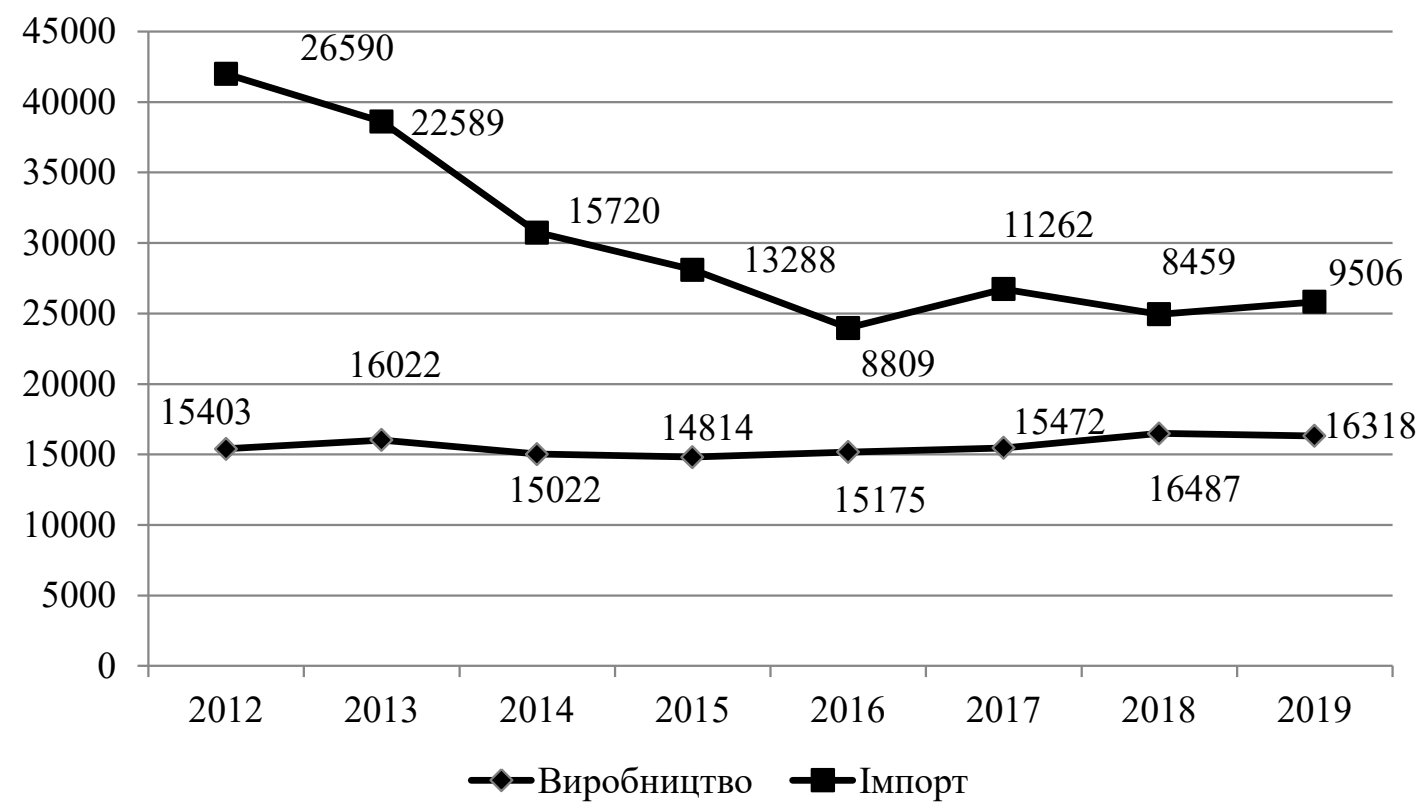

Рис. 1. Динаміка виробництва та імпорту природного газу, тисяч тонн нартового еквіваленту

Джерело: побудовано авторками за [8]

відношення до формуючого та підсумкового рішення на рівні програми та перевірки гіпотез.

1. Реструктуризація. На основі чого буде здійснюватися діяльність, і яка буде роль приватних підприємств у цьому процесі? Обґрунтування конкурентних точок зору щодо значення, яке слід надавати інноваціям при модернізації ГТС, а також для зміцнення виробничих мереж. Яка цілеспрямована позиція у встановленні пріоритетів серед споживачів та галузей? Враховуючи планові або природні зміни в стратегії модернізації, оцінка допомогла б визначити ефективність чистих або змішаних стратегій.

2. Технологічна інфрраструктура. Просторовий, а також галузевий вимір модернізації ГТС покликаний покращити економічні показники держави та природу потенційних взаємних відносин між встановленими центрами модернізації та іншими елементами технологічної інфрраструктури регіону.

3. Державне управління. Різноманітний набір організацій (університети, державні органи, некомерційні організації) приймають участь в процесі розробки механізму оцінки модернізації ГТС. На результативність центрів модернізації впливає ступінь їх інтеграції з іншими організаціями, що надають пов'язані послуги 3 модернізації ГТС. Відповідно, необхідно враховувати важливість міжорганізаційних зв'язків у забезпеченні модернізації.
4. Фінанси. 3 огляду на необхідність фрінансування процесу модернізації ГТС, виникає питання, які типи формул фрінансування слід використовувати на довгострокову перспективу. Які наслідки чи співвідношення поточного фрінансування серед внутрішніх та зовнішніх джерел фрінансування впливає на ефрективність модернізації ГТС ? Яка еластичність попиту на послуги з огляду на встановлення визначеної плати за послуги?

5. Дизайн оцінки процесу модернізації гТС. Початковою точкою для цієї оцінки був насамперед квазіекспериментальний дизайн, тому що багато досліджень ігнорують загрози для внутрішньої та зовнішньої дійсності, а тому квазіекспериментальний дизайн видається найбільш правдоподібним і можливим сильним каркасом для мінімізації таких загроз. Але інші методи оцінки можна використовувати ефективніше, ніж вони використовуються в даний час. Зокрема, рандомізовані експерименти, хоча ті чи інші рандомізовані оцінки можуть бути непростими у здійсненні, досвід у багатьох інших областях засвідчує їх доцільність.

6. Оцінка процесу модернізації. Підвищені вимоги та очікування щодо методологічної строгості, швидше за все, мають обмежений досвід оцінки, а також спочатку невизначена і міняється ціль такої оцінки. Оцінка процесу модернізації ГТС - це набір процедур, призначених для встановлення готовності до більш систематичної, підсумкової модернізації, може 
бути важливим етапом оцінки в такому випадку. Оцінка процесу модернізації вивчає структуру програми модернізації, перевіряє, чи пов'язана послідовність наданих послуг та очікувані результати, враховує готовність для оцінки.

7. Навчання та переймання досвіду. Якими мають бути знання та попередній досвід, включені в програми модернізації? Навчання здійснюється при взаємодії із навколишнім середовищем, отримуючи інсрормацію, діючи на неї та впроваджуючи нові практики щодо рутинних операцій та модернізації системи. Наскільки наближаються програми модернізації та технічної допомоги до проблем екології та економіки, в першу чергу, з точки зору технологічних недоліків, а не організаційної неефективності; існує ризик запропонувати рішення неправильної проблеми або запропонувати рішення способами, які не відповідають сприйняттю своїх потреб.

8. Вимірювання економічних вигод та витрат. Наскільки здійсненними є витрати, пов'язані 3 ними економічні методи вимірювання ефрективності та ефрективність оцінки програм модернізації газотранспортної системи? Наскільки застосовані методи оцінки, що використовуються для обчислення загальних та соціальних норм повернення до технологічних інновацій, та академічні дослідження програм модернізації? Хоча початкові відповіді на ці питання можуть бути орієнтовними та недосконалими, тим не менше вони можуть прокласти шлях до вдосконалених методів оцінки. Без вдосконалення вимірювання економічних наслідків, увага залишатиметься зосередженою на проміжних показниках, які недосконало пов'язані 3 кінцевими показниками результатів.

Організації, які не схильні до ризику, зазвичай вибирають еволюційний метод. Підхід еволюційної модернізації - це багатоетапна, довгострокова модель для досягнення тих самих цілей, що і революційний підхід. 3 еволюційним підходом організації йдуть шляхом навантаження на модернізацію, модернізуючи по одному навантаженню за раз. Цей більш повільний підхід зменшує зриви у діяльності та розподіляє витрати з часом. Організації, укладені у контракти 3 постачальниками, можуть застосувати такий підхід для модернізації навколишньої системи, поки чекають закінчення терміну дії контрактів. Крім того, гібридні моделі дозволяють організаціям підключати аутсорсингові ресурси.

Щоб прийняти рішення між еволюційним або революційним підходом, слід почати 3 ретельної оцінки своїх операцій, щоб визначити найкращий шлях уперед. Процес оцінки повинен включати оцінку наступних міркувань:

1. Навантаження. Перевірка забезпечення, щоб визначити його ділову цінність, критичність та можливості модернізації. Оцінка робочого навантаження цілісно в контексті подальшого розвитку ГТС.

2. Архітектура. Перегляд елементів інфрраструктури, ефективність та рентабельність інвестицій, щоб оцінити, де новіші технології можуть принести кращі результати.

3. Фінанси. Оцінка витрат, щоб знайти обтяження бюджету та шляхи оптимізації ресурсів для підтримки поточних операцій та підготовки до подальшого.

4. Ризик. Зваження можливих зривів в діяльності, а також будь-які пов'язані з цим впливи на бізнес-процеси та організаційну культуру щодо бажаних результатів проекту модернізації застарілої системи. Також врахування ризиків збереження застарілої системи такою, яка $\epsilon$, включаючи технічне обслуговування систем, що не підтримують, або тих, у яких персонал 3 обмеженою ресурсною підтримкою.

5. Операції. Визначення, які нові набори навичок, навчання та процеси потрібно врахувати у витратах на модернізацію та термінах.

6. Безпека. Планування способів захисту діяльності до, під час та після модернізації, щоб уникнути втрат, перебоїв у роботі та впливу зовнішнього середовища. У плані безпеки організації необхідне підтвердження дотримання урядових та галузевих норм у нових умовах.

Необхідно зазначити переваги модернізації застарілої ГТС. Модернізація пропонує такі виграші:

- операційна ефективність: модернізована система забезпечить кращу продуктивність, швидший час транспортування та кращий досвід для внутрішніх та зовнішніх клієнтів;

- зниження витрат: виведення 3 експлуатації неефективного обладнання зменшує витрати на забезпечення діяльності;

- оптимізація процесів, адаптація до умов бізнесу або швидке використання інноваційних можливостей, щоб перемогти своїх конкурентів на глобальному ринку.

До фракторів, що змушують приймати бізнес-рішення для проведення модернізації застарілої газотранспортної системи, належать:

1. Вартість: застаріла інфрраструктура коштує на підтримку більше, ніж модернізована інфрраструктура. 
2. Безпека: одним з найбільших ризиків непідтримуваної застарілої інсрраструктури $є$ відсутність системи безпеки, або труднощів у дотриманні оновлень, які можуть зробити систему неефективною.

3. Відповідність: оскільки регуляторний аудит та контроль стають жорсткішими, застаріла система не в змозі йти в ногу з процесами, необхідними для підтримки конкурентоспроможності.

4. Конкуренція: без модернізованої системи практично неможливо йти в ногу з вимогами міжнародного досвіду та виводити на ринок новітні послуги перед конкуренцією.

5. Продуктивність: модернізація сприятиме підвищенню продуктивності газотранспортної системи.

Пропонується ідея розрахунку оптимальної потужності транзиту як продовження економічної диспетчеризації для визначення оптимальних параметрів керуючих змінних щодо різних обмежень. У цій статті подано огляд оптимальної потужності транзиту та його застосування до ГТС.

Проблема оптимальної потужності транзиту намагається оптимізувати стабільну роботу газотранспортної системи стосовно об'єктивного F, з урахуванням різних обмежень.

Математично проблему оптимальної потужності транзиту можна визначити наступним чином,

$$
\min F(x ; u)
$$

за умови

$$
\begin{aligned}
& \mathrm{g}(\mathrm{x} ; \mathrm{u})=0 \\
& \mathrm{~h}(\mathrm{x} ; \mathrm{u}) \leq 0
\end{aligned}
$$

де $F(x, u)$ - цільова фрункція, що підлягає оптимізації,

$\mathrm{g}(\mathrm{x} ; \mathrm{u})$ являє собою нелінійні обмеження рівності з рівнянь вузлових потужностей,

h $(x ; u)$ становить обмеження нелінійної нерівності на залежні та незалежні змінні.

Вектор х включає залежні змінні, такі як напруга (PQ) вузла, генератор реактивної потужності, тоді як и - вектор керуючих змінних, включаючи величини напруги на вузлі, вихідна активна потужність тощо. Деякий контрольовані змінні мають вартість. Інші не мають вартості. Наведені нижче списки показують вибір цілей та обмежень, які зазвичай зустрічаються при моделюванні оптимальної потужності транзиту. Відомо, що цілі повинні бути математично побудованими 3 можливими рішеннями, а також обмеження повинні бути спроектовані таким чином, щоб задовольнити верхні та нижні межі для отримання можливих рішень. Для оптимальної модернізації ГТС або врахування соціальних та екологічних наслідків модернізації, розрахунок оптимальної потужності транзиту в основному заснований на методі статичної оптимізації для оптимізації скаляра цільової фрункції (наприклад, вартості модернізації).

Розглянемо існуючі підходи до модернізації застарілої ГТС. Існує декілька загальних підходів до модернізації застарілої системи, кожен зі своїм ступенем складності та виграшу. Правильний варіант допоможе як зменшити витрати, так і підвищити ефрективність діяльності:

1. Замінити. Повністю вивести з експлуатації та замінити існуючі застарілі компоненти. При такому підході організація повністю відмовляється від існуючої системи і замінює її абсолютно новою системою, враховуючи нові вимоги та змінені або оптимізовані бізнес-процеси.

2. Відновити. Матеріально реструктуризувати та оптимізувати застарілі елементи системи. Повна перебудова - це найдовший і найдорожчий маршрут, але він приносить максимум переваг. Поєднання методології та технології забезпечує більшу гнучкість, кращі показники та нижчі експлуатаційні витрати в довгостроковій перспективі.

3. Зберегти. Підтримувати поточне середовище без змін та оновлень може означати, що недостатньо вагомих аргументів для модернізації. Незважаючи на те, що короткострокове рішення може бути збереженим, повинна існувати довгострокова стратегія, яка забезпечує стійкість критичних фрункцій. Як правило, утримання від модернізації $€$ тимчасовим заходом, а не довгостроковою стратегією. Чим довше залишається неефективна інфрраструктура 3 великим ресурсом, тим менше бюджету та ресурсів для інвестування в інновації.

Зосередившись на бізнес-процесах та на технологіях, керівництво може краще оцінити та підготуватися до всіх наслідків транссрормації, включаючи екологічні та технічні, планувати модернізацію процесів та перепідготовку робітників. Балансування ризику: правильна оцінка фрінансових ризиків, ризиків безпеки та операційних ризиків рішення про модернізацію $є$ критично важливою. Але у багатьох випадках важко знайти правильні дані для прийняття рішень та досягнення консенсусу серед зацікавлених сторін.

Висновки та перспективи подальших досліджень. В оцінках впливу розвитку технологій та програм модернізації ГТС часто 
виникають труднощі із дотриманням передбачених методологічних стандартів. Пропонується прагматичний підхід до вдосконалення поточної практики оцінки модернізації ГТС. Хоча для проведення оцінки важливо прагнути і дотримуватися норм, практика може бути вдосконалена шляхом використання технічних досягнень, технологічних кордонів оцінки та методології. Нормою для майбутніх дій $є$ не одне дослідження, яке задовольняє всім нормам, а послідовність досліджень, які критикують та вдосконалюють одне одного, як вони колективно просуватися до норм офріційної методології оцінки модернізації ГТС. Акцент слід зробити на послідовній та всебічній програмі оцінки модернізації ГТС.

\section{СПИСОК ВИКОРИСТАНИХ ДЖЕРЕЛ:}

1. Бобрівець С. Державне регулювання ринку газопостачання: економічна суть та методи управління. Українська наука: минуле, сучасне, майбутнє. 2003. Вип. 8. С. 21-26.

2. Перевозова І.В. Моніторинг сучасних умов фрункціонування підприємств насртогазової галузі України у контексті світового досвіду. Науковий вісник Херсонського державного університету. Серія «Економічні науки». 2015. № 5(11). С. 74-76.

3. Крижанівський Є.І., Дзьоба О.Г., Джус А.П., Міронов Ю.В. Техніко-економічні аспекти транспортування природного газу із морських родовищ. Науковий вісник Івано-Франківського національного технічного університету нафти і газу. 2013. № 2. С. 7-15.

4. Кулицький С. Оцінка перспектив розвитку української газової сфери в контексті ймовірних змін у логістиці газового ринку Європи. Україна: події, фракти, коментарі. 2017. № 6. С. 51-67. URL: http://nbuviap.gov.ua/ images/ukraine/2017/ukr6.pdf

5. Кучмистенко О.В. Аналіз режимів функціонування української газотранспортної системи як об'єкта управління. Нафртогазова енергетика. 2013. № 1. C. 68-80. URL: http://nbuv.gov.ua/UJRN/Nge_2013_1_8

6. Лінчевська Н.М., Дзьоба О.Г. Аналіз чинників та організаційно-економічних інструментів забезпечення інноваційного розвитку газотранспортних підприємств. Науковий вісник Івано-Франківського національного технічного університету нафрти і газу. Серія «Економіка та управління в насртовій і газовій промисловості». 2014. № 1(9). С. 47-55.

7. Полянська А.С. Пріоритети розвитку зовнішньоекономічної діяльності підприємств нафртогазового комплексу на шляху до інтеграції вітчизняного Пек у європейський економічний простір. Науковий вісник ІваноФранківського національного технічного університету нафтти і газу. 2013. № 2(35). С. 213-220.

8. Сайт державної служби статистики України. URL: http://www.ukrstat.gov.ua/

\section{REFERENCES:}

1. Bobrivets, S. (2003). Derzhavne rehuliuvannia rynku hazopostachannia: ekonomichna sut ta metody upravlinnia [State regulation of the gas supply market: economic essence and management methods]. Ukrainska nauka: mynule, suchasne, majbutnie - Ukrainian science: past, present, future, vol. 8, pp. 21-26. (in Ukrainian)

2. Perevozova, I.V. (2015). Monitorynh suchasnykh umov funktsionuvannia pidpryiemstv naftohazovoi haluzi Ukrainy u konteksti svitovoho dosvidu [Monitoring of modern conditions for the functioning of enterprises in the oil and gas industry of Ukraine in the context of world experience]. Naukovyj visnyk Khersons'koho derzhavnoho universytetu Seriia «Ekonomichni nauky» - Scientific Bulletin of Kherson State University Series "Economic Sciences", vol. 5(11), pp. 74-76. (in Ukrainian)

3. Kryzhanivskyj, Ye.I., Dzoba, O.H., Dzhus, A.P., Mironov, Yu.V. (2013). Tekhniko-ekonomichni aspekty transportuvannia pryrodnoho hazu iz mors'kykh rodovysch [Technical and economic aspects of natural gas transportation from offshore fields]. Naukovyj visnyk Ivano-Frankivs'koho natsionalnoho tekhnichnoho universytetu nafty $i$ hazu. Seriia «Ekonomika ta upravlinnia v naftovij i hazovij promyslovosti» - Scientific Bulletin of Ivano-Frankivsk National Technical University of Oil and Gas. Series "Economics and Management in the Oil and Gas Industry", vol. 2, pp. 7-15. (in Ukrainian)

4. Kulitsky, S. (2017). Otsinka perspektyv rozvytku ukrains'koi hazovoi sfery v konteksti jmovirnykh zmin u lohistytsi hazovoho rynku Yevropy. [Assessment of prospects for the development of the Ukrainian gas sector in the context of probable changes in the logistics of the European gas market]. Ukraina: podii, fakty, komentari - Ukraine: events, facts, comments, vol. 6, pp. 51-67 Retrieved from: http://nbuviap.gov.ua/images/ukraine/2017/ukr6.pdf (in Ukrainian)

5. Kuchmystenko, O.V. (2013). Analiz rezhymiv funktsionuvannia ukrains'koi hazotransportnoi systemy iak ob'iekta upravlinnia [Analysis of the modes of functioning of the Ukrainian gas transportation system as an 
object of management] Naftohazova enerhetyka - Oil and gas energy. Retrieved from: http://nbuv.gov.ua/UJRN/ Nge_2013_1_8 (in Ukrainian)

6. Linchevska, N.M., \& Dzoba, O.H. (2014). Analiz chynnykiv ta orhanizatsijno-ekonomichnykh instrumentiv zabezpechennia innovatsijnoho rozvytku hazotransportnykh pidpryiemstv [Analysis of factors and organizational and economic tools to ensure the innovative development of gas transmission companies]. Naukovyj visnyk Ivano-Frankivs'koho natsionalnoho tekhnichnoho universytetu nafty i hazu. Seriia «Ekonomika ta upravlinnia $v$ naftovij i hazovij promyslovosti» - Scientific Bulletin of Ivano-Frankivsk National Technical University of Oil and Gas. Series "Economics and Management in the Oil and Gas Industry", vol. 1(9), pp. 47-55. (in Ukrainian)

7. Polyanskaya, A.S. (2013). Priorytety rozvytku zovnishn'oekonomichnoi diial'nosti pidpryiemstv naftohazovoho kompleksu na shliakhu do intehratsii vitchyznianoho Pek u ievropejs'kyj ekonomichnyj prostir [Priorities of development of foreign economic activity of oil and gas complex enterprises on the way to integration of domestic Peck into the European economic space]. Naukovyj visnyk Ivano-Frankivs'koho natsionalnoho tekhnichnoho universytetu nafty $i$ hazu. Seriia «Ekonomika ta upravlinnia v naftovij i hazovij promyslovosti» - Scientific Bulletin of Ivano-Frankivsk National Technical University of Oil and Gas. Series "Economics and Management in the Oil and Gas Industry", vol. 2(35), pp. 213-220. (in Ukrainian)

8. Sajt derzhavnoi sluzhby statystyky Ukrainy [State Statistics Service of Ukraine]. Retrieved from: http://www.ukrstat.gov.ua/ 